\title{
The shape of a transforming educational process in post-industrial society
}

\author{
Lyubov N. Ruliene ${ }^{1, *}$, and Sergey D. Namsaraev ${ }^{1}$ \\ ${ }^{1}$ BSU, 670000, Ulan-Ude, Russia
}

\begin{abstract}
This paper presents contemplations about possibilities and risks of postindustrial society and impressions of the prospects of post-industrial education. It considers peculiarities of electronic information and educational environment (EIEE) in a modern university. The paper determines conditions for an efficient functioning of the EIEE and the role of e-learning tutor. The authors express the idea about a necessity to humanize the information and educational interaction of students and faculty. In their view, the role of tutor lies in knowledge management allowing enhancement of educational process in the EIEE. The paper substantiates the topicality of tutor support of e-learning. It introduces the Master's program under the name "Organization and Support of E-Learning" and characterizes competences formed, which reflect the specifics of teaching activity of an elearning tutor. The authors pay attention to the necessity of searching for technologies, which ensure the humanization of students and faculty activity in the electronic information and educational environment.
\end{abstract}

In characterizing the contemporary society we use a term "post-industrial society" as a social form reflecting evolution and transformation of all spheres of postindustrial society. Descriptions of an image of postindustrial society (D. Bell, E. Masuda, F. Webster, F. Fukuyama, V.L. Inozemtsev and others) present its essential characteristics, such as the primacy of information product, globalization of economy based on the development of network information streams, management of international and domestic problems through information systems, transformation of information into workforce, ingression of computerization in all spheres of labor, boosting influence of IT-specialists and analysts, special role of technology and technological assessments and creation of a new "intellectual technology." Therefore, we define it as a post-industrial information society.

The entry of the humanity in the post-industrial epoch is characterized by radical changes in informative, processual and institutional shapes of education. Not merely contents, but also aim and motifs of education undergo changes in the post-industrial society and a teacher's image is transformed. A new educational practice is underway in pedagogy. It is the postindustrial education practice (A.M. Novikov), in which technologies of e-learning and online training and various models of e-learning information environments are developed.

Clearly, the modern stage of the post-industrial information society can be defined as technologized. A technologized society is based on the use of a qualitatively different resource, a creative potential of a person [1], in whose development humanitarian technologies play a decisive role. The value of the humanitarian technologies in the context of human qualities development in the modern post-industrial society is determined by the fact that their foundations are principles of openness and dialogue, continuous interaction and feedback, interactivity, reflexive assessment of one's own activity, and a free choice of offered services.

All life processes, including educational processes, are characterized by technologization. The most cuttingedge modern technologies, such as microelectronics, computing tools, robotics, nanotechnologies and biotechnologies are marked by research intensity, resource conservation and a high degree of organization. This enables them to be constantly updated, competitive and forward-looking. In our view, educational process in the post-industrial information society should be considered a high-tech process since it is carried out in the academic environment supersaturated with information, and requires high intellectual, informational and communicative competence of faculty and students. It is also orientated towards constant updating of educational technologies. Faculty members and students who systematically and effectively use information and communication technologies in their routine work with high level of digital competence are agents of change in the higher education practice.

However, nowadays the enhancement of informational and communicative competence

\footnotetext{
Corresponding author: $\underline{\text { lubovruliene@gmail.com }}$
} 
presupposes not so much the development of technological skills as the formation of moral and ethical behavior culture in the information society. Today we live in the conditions of virtual publicity modeled by social networks, such as Facebook, Odnoklassniki or VKontakte. New forms of sociality and publicity emerged. Personal life has become too open ("we live on a big street") and borders between public and private disappear. Hence, the objective of educational institutions is to direct network activity towards positive opening up of the living space and preservation of the moral and patriotic value orientation.

It is very important because a pragmatic attitude to life and a human desire to get beyond human nature start to prevail in the modern world [2]. It has been affirmed that a man gradually dissolves in the modern world. He is already partially dissolved and will surely totally disappear at some moment [3]. The man will be replaced by a global principle of organization of all manifestations of human knowledge. With the advent of a "post-human" reality the world of machines will take care of men [4]. According to the concept of posthumanism man entered into such a close contact with machine that the border between the artificial and the natural will eventually disappear. Man loses the uniqueness of his personality; integrated technologies in the entire world form a universal man.

Another, more radical, challenge to the idea that human condition always stays unchanged is transhumanism. This scientifically oriented worldview accepts possibility and desirability of fundamental changes in men attained through advanced technologies and aimed against suffering, ageing and death by means of strengthening physical, intellectual and psychological human abilities. Proponents of this trend hope to create super-intellectual machines by "technological means", ensure emotional well-being by recalibrating reward center, and develop individuality pills. They want to colonize the outer space, create molecular nanotechnology, forecast catastrophes (e.g. destruction of intelligent life), transfer human consciousness to virtual world and resuscitate frozen patients. Such posthuman intentions cannot fail to upset the pedagogical and academic communities.

In order to solve such problems it is necessary to search for imperatives providing immunity to global upheaval and challenges. Much depends on social institutions, most of all, education. The fate of modern civilization heavily depends on what educational values will be like. Education always was, is, and will be a means of transmission of social experience. It may and should act as an institute of search for new values and a form of investment in the future. The goal of education is in forming skills of interaction with nature, machinery and people; competence in using acquired knowledge for making right decisions, and ability to live preserving ourselves spiritually, intellectually and physically [5, p. 192]. Organizational and pedagogical mechanisms are required, which will help to "leave human to a human" [6] and work to attain the goal that men in the nearest future will try to remain human.
Considering education as a part of life one should more actively use possibilities of informal training or lifetime learning. Informal education is accomplished by means of personal activity of a man in the process of communication, reading, visiting cultural establishments, traveling and via mass media. Despite a spontaneous character of informal education its subjects are characterized by a high degree of organizational and cognitive independence and striving for intra-group and inter-group cooperation.

We observe that the educational process increasingly needs shaping of special, properly human forms of attitude to the real and, nowadays, also virtual world; to ourselves (Who am I in this global information world?), our own activities (What can I do? What should I do? What do I want?). Relationships of the members of educational interaction are developed in the context of subject-oriented approach [7; 8], which allows surmounting the dominance of normative over subjective and bureaucratic over academic, and use synthetic methods of problem solving.

Education is meant to make labor of every man more productive by ensuring the development of universal skills in the process of mastering the constantly updating professional technologies. The necessity of developing innovative skills in trainees requires constant modernization of educational process, creation, implementation and dissemination of new educational technologies. It demands active development of teaching methods using cutting-edge information, psychological and applied learning technologies, interactive forms of education, use of electronic educational resources, and implementation of new educational technologies with the focus on active and interactive forms. All this requires the development of educational process on the basis of openness to the future and the ability to foresee constant reappraisal of values and joint actions in new situations $[9$, p. 11].

E-learning development is the key component of the contemporary educational infrastructure and an important direction of Russian state policy in the field of education (Federal Law \# 273-FZ "On Education in the Russian Federation", "Our New School" initiative, etc.). In a session of the State Council on enhancement of comprehensive and secondary education held on 23.12.2015, during a meeting of the Council on Science and Education (21.01.2016) and consultation of President Vladimir Putin with the government (27.01.2016) it was affirmed that the contemporary Russian society displays an ever growing demand for elearning. Russia launched such projects as "E-learning for the Disabled" and "Education in Russian." The "Online Education" portal will be launched in December 2016. It will provide officially certified secondary schooling.

The electronic information and educational environment (EIEE) is the key infrastructure of a modern university and its significance continues growing. Yet if ten years ago the development of EIEE meant its saturation with electronic informational and educational resources, implementation of information and telecommunication technologies and development of 
technological means, at present the most important thing is to "revive" and emotionally saturate the informational and educational interaction of students and instructors. Trends of interactive e-learning are an efficient means to solve this issue. They are online conferences, webinars, demo-tours, postings, Google-based applications, game mechanics (gamification), mobile communication tools, such as plickers and quick keys, etc. The use of such tools in the educational process enables us to move beyond "static" digestion of knowledge to "dynamic" peer and self-tuition.

Within the EIEE the traditional enrollment management and administration structure is replaced by a community of students, university faculty and staff. Relationships between members of the community are horizontally built. A tutorial, an informal group meeting of the community members is the governing body. As a rule tutorials are concentrated on the issues of development and support of online courses. Discussing methods and techniques of information and educational environment (IEE) content enhancement instructors and curriculum developers exchange implicit knowledge of how to quickly upload test materials, automatically calculate scores for accomplished assignments, set up a glossary, integrate Wiki-pages, change a course avatar, etc.

Obviously, the most important conditions for efficient functioning of the EIEE are the adaptability of the environment (an ability to administer it according to user needs and requests), openness of its participants (readiness to master new methodologies and services), and presence of an institute of tutors from the ranks of instructors and curriculum developers capable of consulting and discussing ways of enhancement of the EIEE. In our view, the role of tutors is in the externalization of knowledge, i.e. transfer of nonformalized academic and methodological knowledge accumulated through practice to the formalized one, that is, to visible clear instructions open for use by other instructors in the process of development and implementation of online courses. Tutors assist the instructors to present personalized non-formalized knowledge (on "know-how") concisely, clearly and intelligibly in a course summary. Essentially, we speak about knowledge management skills. The experience shows that the process of implicit knowledge exchange is the main difficulty in knowledge management. Since explicit knowledge is formalized, systematic and expressed in a form of words and digits, it can be transmitted in a formalized way through various media, such as documents, instructions, floppies, memos and so on. Implicit knowledge is very personal as it is associated with intuition, insight, conjectures, ideals and values [10, p. 199]. It is hard to formalize and, therefore, transmit to others [11, p. 69]. It can exist only with its holder. Transmission of implicit knowledge is possible in the process of performing individual action, implementation of proprietary teaching technology and so on. Therefore tutors must acquire functions of protocoling, analyzing and generalizing seminar answers. Methodological recommendations, video instructions, demo-lessons and other products are created on the basis of this data. Tutors should constantly formulate, describe and reflect procedures of routine work. In this way a bank of decisions and algorithms is created. This function is implemented in the section "Suggestions, Help, FAQ" on the e-learning portal of the Buryat State University.

For the support of post-industrial education training of e-learning tutors is are required. They should be able to study the educational process in the context of IT development, enhance educational practice within elearning, generalize and develop the domestic and international experience of e-learning organization, and carry out a scientific study of the problems in the field of e-learning both independently and as a part of a pedagogical network community. They will also participate in designing and implementation of educational models, programs and projects in the field of e-learning and carry out a psychological and pedagogical expertise of e-learning.

Taking into account the topicality of tutor support of e-learning, in 2016 the Buryat State University began enroilment in the Master's program "Organization and Support of E-Learning." Besides the development of common cultural professional competences this Master's program is aimed at the development of special competences in compliance with ICT-CFT. Among them we highlight the following skills: to use conventional teaching methods in the EIEE; use interactive means of network communication and cooperation; apply ICT for the organization of individual and group student work in e-learning and mixed education; determine in which conditions it is efficient/inefficient to use certain ICT means; utilize ICT means to improve their performance; explain and analyze principles of ICT use in education based on their own practice; assess credibility and relevance of web-resources; use the Internet as a tool for teamwork of high-school students at school and beyond (fill the virtual space with educational content); supervise project work of high-school students in an ICT-saturated educational environment; use ICT for communication with external experts and educational communities; assist students in using ICT for selfeducation; describe functions and purpose of virtual media and systems for knowledge management; describe functions and purpose of tools for plan preparation and analytical work; play a leading role in the development of an ICT implementation strategy for routine teaching practice; use ICT means for participation in professional associations and communities; exchange and discuss best teaching practices. These ICT-competences reflect the specificity of educational activity of an e-learning tutor.

Thus, information and knowledge are the most significant resources for the development of modern society available to those who consistently enhance their economic and cultural status by high aptitude for learning and continuous growth of professionalism. Development of these qualities is possible in lifetime learning. A lifetime learner always updates his life experience and increases functional literacy and, therefore, is valuable for the society that is interested in high workforce productivity. Therefore, potential abilities of the post-industrial society in which 
professionalism becomes a social position criterion (D. Bell) should be sought not only in the development of science, technology and production, but also in a consistent increase of education level of the citizens. Enhancement of educational process based on the extensive use of information and communication means and technologies is a way to solve this problem and a prospective development trend for teaching theory and practice. However, the global information system development results in computers being able to spread new forms of literacy, but unable to satisfy those intellectual needs that they stimulate themselves (E. Umberto). The Internet boosts globalization. Unfortunately, at the same time it intensifies deformation of communicative relations (e.g. such phenomena as indirectness, facelessness, fragmentariness and so on). Thus, a search for technologies, which ensure humanization of student and faculty activity in the EIEE, integrate data transmission facilities, information resources, interconnection protocols, hardware and software, organizational and methodological support should be among the topical issues of modern research and development in education. Launching of the Master's program "Organization and Support of ELearning" is one of the ways to ensure humanization of the EIEE.

\section{References}

1. V.L. Inozemtsev, Sovremennoe postindustrial'noe obshchestvo: priroda, protivorechiya, perspektivy. (Logos, Moscow, 2000) [In Rus]
2. E.A. Sakirko, Oppozitsiya estestvennoe-iskusstvennoe $v$ sovremennom kul'turologicheskom i khudozhestvennom diskurse (Pashkov dom, Moscow, 2011) [In Rus]

3. M. Foucault. The Order of Things. An Archaeology of the Human Sciences (A-cad, St.Petersburg, 1994) [In Rus]

4. O.A. Pechenkina, Etika simulyakrov Zh. Bodriyyara: (analiz postmodernistskoy retseptsii eticheskogo) (Tul'skiy poligrafist, Tula, 2011) [In Rus]

5. S.V. Ivanova, Obrazovanie $v$ organizatsionnogumanisticheskom izmerenii (Rossiyskiy un-t druzhby narodov, Moscow, 2007) [In Rus]

6. G. Malinetskiy, Slozhnost', nestabil'nost' $i$ sud'ba Rossii. Available online: URL http://www.intelros.ru/index.php?newsid=50 (accessed on: 31.05.2006) [In Rus]

7. Problemy sub"ektov $v$ postneklassicheskoy nauke (Kogito-Tsentr, Moscow, 2007) [In Rus]

8. V.E. Lepskiy, Sub"ektno-orientirovannyy podkhod $k$ innovatsionnomu razvitiyu (Kogito-Tsentr, Moscow, 2009) [In Rus]

9. A.M. Novikov, Osnovaniya pedagogiki (Izdatel'stvo Egves, Moscow, 2010) [In Rus]

10. A.L. Gaponenko, Upravlenie znaniyami: kak prevratit' znaniya v kapital (Eksmo, Moscow, 2008) [In Rus]

11. I. Nonaka, A Company as a Creator of Knowledge (Vysshaya shkola menedzhmenta, St.Petersburg, 2010) [In Rus] 